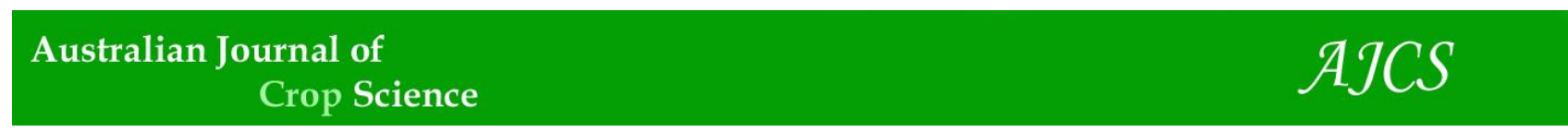

AJCS 10(8):1075-1082 (2016)

ISSN:1835-2707

DOI: 10.21475/ajcs.2016.10.08.p7175

\title{
Morphometry, in vitro-ex vitro germination and tetrazolium testing of stinking passionflower [Passiflora foetida var. glaziovii Killip] (Passifloraceae) seeds
}

\author{
Poliana Rangel Costa ${ }^{1}$, João Paulo Bestete de Oliveira ${ }^{2}$, Anderson Geyson Alves de Araújo ${ }^{1}$, José \\ Carlos Lopes $^{3}$, Edilson Romais Schmildt ${ }^{1}$, Wagner Campos Otoni ${ }^{4}$, Rodrigo Sobreira Alexandre ${ }^{5, "}$
}

\author{
${ }^{1}$ Federal University of Espírito Santo, Department of Agricultural and Life Sciences, Brazil \\ ${ }^{2}$ Federal Institute of Espírito Santo, Campus Ibatiba, Brazil \\ ${ }^{3}$ Federal University of Espírito Santo, Department of Plant Production, Brazil \\ ${ }^{4}$ Federal University of Viçosa, Department of Plant Biology/BIOAGRO, Brazil \\ ${ }^{5}$ Federal University of Espírito Santo, Department of Forest Sciences and Wood, Brazil
}

*Corresponding author: rodrigosobreiraalexandre@gmail.com

\begin{abstract}
Passiflora foetida L. has broad utility as a medicinal and ornamental plant; however, information regarding varieties and the physiological potential of their seeds are scarce. Here, we aim to evaluate in vitro and ex vitro germination behaviour and to adapt tetrazolium methodology for $P$. foetida var. glaziovii Killip. The botanical identification and characterisation were performed through the observation of morphological characters and consultation of the relevant literature. Ex vitro germination was performed on rolled and flat Germitest paper at continuous $\left(25^{\circ} \mathrm{C}\right)$ and alternating $\left(20\right.$ and $30^{\circ} \mathrm{C}$; night and day, respectively) temperatures. Seeds with the completely removed integument were used for in vitro germination and tetrazolium tests. The in vitro germination test was performed with MS medium using seeds conditioned under different light qualities (white, red, far-red or darkness) and at two temperature regimes $\left(25{ }^{\circ} \mathrm{C} ; 20\right.$ and $30{ }^{\circ} \mathrm{C}$ alternating temperature). For the tetrazolium test, seeds were soaked in different concentrations of tetrazolium salt $\left(2.5,5.0,7.5\right.$ or $\left.10 \mathrm{~g} \mathrm{~L}^{-1}\right)$ at different temperatures $\left(30,35,40\right.$ or $\left.45^{\circ} \mathrm{C}\right)$ for two hours in the dark. This is the first record of $P$. foetida var. glaziovii, a wild herbaceous vine with glandular trichomes on its leaves, bracts and stipules; fruit bacoid, elliptic, glabrous, in Espírito Santo State, Brazil. The seeds are small (approximately $4.87 \mathrm{~mm}$ long and $2.15 \mathrm{~mm}$ wide) and non-photoblastic, and in vitro germination must be performed using an alternating temperature $\left(20\right.$ and $\left.30^{\circ} \mathrm{C}\right)$ regime. The best result of germination was achieved using a concentration-temperature combination of $10 \mathrm{~g} \mathrm{~L}^{-1}$ tetrazolium and $30^{\circ} \mathrm{C}$.
\end{abstract}

Keywords: Wild passion fruit. Propagation. Tissue culture. Light. Temperature.

Abbreviation: MS_Murashige and Skoog, TZ_tetrazolium test, CEUNES_Centro Universitário Norte do Espírito Santo, Herbário VIES_Herbário Vitória-Espírito Santo, UFES_Universidade Federal do Espírito Santo, BOD_Biochemical Oxygen Demand.

\section{Introduction}

Passiflora foetida L. (Passifloraceae) is a self-compatible species (Faria and Stehmann, 2010) that is an important ornamental, medicinal, and ethnic plant. The species bears glandular trichomes, which can be found mainly on the bracts, stipules, and leaves. These trichomes produce a secretion that exhibits high protease, phosphatase, passifloricin, and alpha-pyrone-based insecticide activities as well as other substances that may inhibit the activity of metallo-proteases involved in tumour invasion, metastasis, and angiogenesis (Rosa and Dornelas, 2012). Considering the abundant compounds, it is clear why many studies have suggested the utilisation of $P$. foetida for the treatment of several diseases, including skin diseases, dizziness, headache, insomnia, hysteria, and anxiety, due to its antibiotic, sedative and antispasmodic properties (Rasool et al., 2011; Sathish et al., 2011). With respect to the great morphological variability of the species, the taxonomy of $P$. foetida infraspecific names is unclear and remains a primary focus for study (Araújo and Alves, 2007). According to the main global taxonomic databases (IPNI, 2013; The Plant List, 2013; Tropicos, 2013), there is currently still no consensus concerning the validity of Killip's names.
Among $P$. foetida varieties, $P$. foetida var. glaziovii is the variety most easily found in the North of Espírito Santo State, Brazil. This variety may bear some interesting features in terms of its physiology and seedling growth, as the plants can be grown in open, well-drained and pest-unprotected areas. According to Preisigke et al. (2015), this species also possesses the important feature of being highly resistant to Fusarium solani. The establishment of quality patterns requires an understanding of viable propagation methods and is dependent on information regarding the propagation and physiological potential of $P$. foetida var. glaziovii (Pires et al., 2012). Germination and tetrazolium (TZ) tests are among the main methods for evaluating the physiological potential of seeds, and the correct application of these methods is very important for generating satisfactory results for this species. Additionally, knowledge of the optimal conditions for the germination process in a species is essential; water, light, and temperature are the most relevant factors and are intricately linked to the metabolic pathways that function during germination (Baskin and Baskin, 1988). Similarly, for the TZ test, it is necessary to identify aspects such as the preconditioning, staining, and concentration of the TZ 
solution as well as the time and temperature conditioning of the seeds. These steps will directly affect the intensity and uniformity of staining patterns; thus, if these factors are not well controlled, they may generate misinterpretations and uncertain results (Gaspar-Oliveira et al., 2009; Souza et al., 2010).

This work aims to describe the morphology of the species $P$. foetida var. glaziovii, to evaluate its germination behaviour in vitro and ex vitro and to adapt tetrazolium methodology to this particular variety.

\section{Results}

\section{Morphological description of Passiflora foetida var. glaziovii}

Vines. Stems cylindrical, slender, striated, vinaceous; axillary tendrils; pinnatisect stipules. Leaves 3-lobed, 6.9-8.1 x 3.1$4.2 \mathrm{~cm}$, right lobe $2.0-3.1 \mathrm{~cm}$ width, left lobe $2.3-3.0 \mathrm{~cm}$ width, basis cordate, apex acute, subhastate, adpresso-hirsute above, densely ciliate, tector trichomes on upper leaf side, glandular trichomes on lower leaf side, margin waved, ciliate, presence of glandular trichomes; petioles $3.1-4.9 \mathrm{~cm}$ long, ciliate, presence of glandular trichomes; bracts-3, $2.0-2.5 \mathrm{~cm}$ long, persistent, bipinnatisect, segments shorter than half of midrib, greenish, ciliate, glandular trichomes. Hypanthia short-campanulate, greenish; sepals-5, oblong, corniculate, apex acute, presence of tector trichomes, lower side greenish, upper side whitish; petals-5, oblong, apex rounded, whitish; corona filiform, whitish and purple; nectary ring present; ovary-3 carpelar, glabrous; stigma-3s; stamen-5; fruit bacoid, elliptic, glabrous, greenish; seeds 1.95-2.29 x 4.24-4.93 mm, flat, oblong, blackish, tridentate apex, arillate, aril white (Fig. 1). Examined material: BRASIL. Espírito Santo. São Mateus, Litorâneo, Campus do CEUNES, 01. II. 2013, fl./fr., Costa, P. R. 01(VIES).

\section{Germination potential of $\mathbf{P}$. foetida var. glaziovii seeds}

The seeds have an average moisture content of $10 \%$, and the electrical conductivity measured was $0.694 \mu \mathrm{S} \mathrm{cm}^{-1} \mathrm{~g}^{-1}$. The seeds bear a rigid integument, which exhibits a reticulated surface on the central region. The apex is tridentate on both surfaces, with central projections slightly larger than those on the other parts of the seed, an acute base and a striate margin. The average seed size is as follows: $4.67 \mathrm{~mm}$ length, 2.15 $\mathrm{mm}$ width, and $1.24 \mathrm{~mm}$ thickness. Soaking phases according to triphasic water absorption are presented in Figure 2. Phase I of the soaking process required two hours, during which the moisture content increased from 10 to $12 \%$. Thereafter, the water absorption velocity decreased drastically up to $94 \mathrm{~h}$; this process is phase II, or the lag phase. Water absorption resumed after $96 \mathrm{~h}$, and turgor pressure increased from 12 to $13 \%$ over the course of $24 \mathrm{~h}$. This increase marks the beginning of phase III, during which active water absorption by the seeds occurs. However, there was no water absorption by the seeds after $120 \mathrm{~h}$, and radicle protrusion was not observed. To verify whether germination dormancy was the reason for the absence of radicle protrusion, ex vitro germination tests were performed both in rolls and on paper. However, only one seed was observed to germinate in either test after $30 \mathrm{~d}$ with alternating temperatures of 20-30 ${ }^{\circ} \mathrm{C}$. Once dormancy was detected, an in vitro pre-test was performed to determine the influence of the presence or absence of the integument during the in vitro germination of P. foetida var. glaziovii.
After a week, it was possible to observe high levels of contamination on those seeds with an integument, whereas the seeds that had their integument removed remained clean and showed radicle protrusion. The positive results from the germination evaluation consequently enabled testing the effects of different light qualities and temperatures. Factorial analysis of temperature and light quality revealed no significance; therefore, the treatments were performed separately. After $14 \mathrm{~d}$, there were no differences in the percentage of normal seedlings under the 25 and $20-30{ }^{\circ} \mathrm{C}$ temperature conditions. This changed after $30 \mathrm{~d}$, however, with the percentage of normal seedlings being higher for seeds at $20-30{ }^{\circ} \mathrm{C}$ (Table 1 ). With respect to germination, $P$. foetida var. glaziovii seeds appeared indifferent to light quality, as shown in Table 2. This result suggests a nonphotoblastic behaviour (Fig. 3).

The results of the tetrazolium tests showed thirteen main patterns of staining, and the evaluation of the seedlings from in vitro germination revealed four stages of growth. Thus, it is possible to suggest a pattern with four distinct vitality classes, which were assigned based on the association between embryo staining and seedling development. Embryos with a shiny red colour, a shiny pink colour or both were classified as high-vitality embryos, which can give rise to seedlings with well-developed radicle and stem systems (Class 1) (Table 3).

Embryos showing a light pink colour, with less than $50 \%$ of the cotyledons having no colour or a deep carmine red at the ends of the embryonic axis, were classified as low vitality, giving rise to seedlings with poorly developed stem and hypocotyl systems or even fused cotyledons or to seeds with primary radicle protrusion (Class 2) (Table 3). Embryos with $50 \%$ or more of their cotyledons having no colour and a whitish or a deep carmine red embryonic axis can generate seedlings that are not well developed and that have no radicle system or rosette shape (Class 3) (Table 3). During the analysis, lateral damage to the cotyledons due to pressure from the Mini-Morse vise while removing the integument was detected. This damage was considered unnatural and was therefore not included in the analyses.

Values referring to the association between $\mathrm{TZ}$ and in vitro germination are provided in Table 4. Germination frequencies from the $\mathrm{TZ}$ treatments and in vitro germination experiments were compared using the Chi-squared test. The results showed that the percentage probability values were higher than $5 \%$, which demonstrates that the differences were not statistically significant. Thus, a comparison of the frequencies of viable and unviable embryos revealed that both preconditioning the embryos at ambient temperature for $12 \mathrm{~h}$ in distilled water and conditioning them with 10 or $5 \mathrm{~g}$ $\mathrm{L}^{-1}$ tetrazolium at 30 or $35^{\circ} \mathrm{C}$ for two hours had an $83.03 \%$ probability of producing viable embryos. These results were better than the frequencies from the in vitro germination test, though the difference in the number of viable embryos between the $\mathrm{TZ}$ and germination tests was less than $5 \%$ (Table 4). Comparisons between the frequencies from the TZ and germination tests (Table 5) revealed that conditioning the embryos with $10 \mathrm{~g} \mathrm{~L}^{-1}$ tetrazolium at $30{ }^{\circ} \mathrm{C}$ resulted in the highest significance, with a frequency of $60.40 \%$. These results confirm the results presented in Table 5 that this treatment is optimal for performing tetrazolium tests on the seeds of $P$. foetida var. glaziovii.

\section{Discussion}

This report is the first of Passiflora foetida var. glaziovii in Espírito Santo State; this species was previously only 
Table 1. Percentage of normal and defective seedlings and hypocotyl length (cm) of P. foetida var. glaziovii at different temperatures.

\begin{tabular}{|c|c|c|c|c|}
\hline \multirow{3}{*}{ Temperatures $\left({ }^{\circ} \mathrm{C}\right)$} & \multicolumn{4}{|c|}{ Features } \\
\hline & \multirow{2}{*}{$\begin{array}{c}14 \text { days } \\
\text { Normal seedlings } \\
(\%)\end{array}$} & \multicolumn{3}{|c|}{30 days } \\
\hline & & $\begin{array}{l}\text { Normal } \\
\text { seedlings } \\
(\%)\end{array}$ & $\begin{array}{l}\text { Defective } \\
\text { seedlings } \\
(\%)\end{array}$ & $\begin{array}{l}\text { Hypocotyl } \\
\text { length } \\
\text { (cm) }\end{array}$ \\
\hline 25 & $31.7 \mathrm{a}^{*}$ & $33.5 \mathrm{~b}$ & $52.3 \mathrm{a}$ & $7.7 \mathrm{a}$ \\
\hline $20-30$ & $38.0 \mathrm{a}$ & $46.2 \mathrm{a}$ & $37.2 \mathrm{~b}$ & $7.6 \mathrm{a}$ \\
\hline
\end{tabular}

*Averages followed by the same letter indicate no significant differences according to the Tukey test, $\mathrm{p}>0.05$.

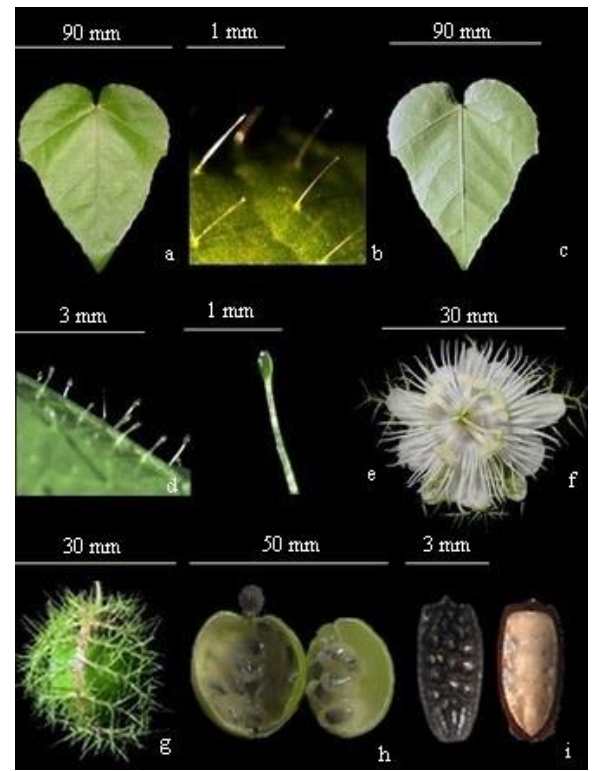

Fig 1. Passiflora foetida var. glaziovii Killip. Adaxial leaf (a); tector trichomes on the upper surface (b); abaxial leaf (c); glandular trichomes on the lower surface (d); glandular trichome (e); flower (f); fruit (g); mature fruit $(\mathrm{h})$; intact seed and seed bearing endosperm with integument removed (i).

recorded from Rio de Janeiro State, Brazil. However, there are reports on P. foetida var. gossypifolia (Desv.) Mast. Trans. Linn. and P. foetida var. fluminensis (M. Roemer) Killip in different areas adjacent to Espírito Santo; the latter is the closest variety and is often confused with $P$. foetida var. glaziovii due to its glabrous ovary. Nonetheless, these species can be distinguished by the absence of trichomes on the vegetative organs, which is not true for $P$. foetida var. glaziovii. Knowledge of the morphological and physiological features of wild Passiflora species is especially important due to their high potential for use in the production of several substances. Indeed, these plants can be used as agricultural defensive and pharmaceutical bioactive crops, as well as for genetic improvement (Oliveira Júnior et al., 2010). There is also evidence concerning the healing properties of Passiflora species used as medicinal plants by the Brazilian people (Silva et al., 2006; Marliére et al., 2008). An important consideration is that medicinal plants are usually cultivated or sold in fairs and street markets, where knowledge is accumulated and often transmitted orally (Verdam and Silva, 2010). Thus, there is a high chance of poisoning due to the chemical content and toxicity of each sample, which may vary by taxon. It is therefore very important to know how to correctly identify the taxon to be used. Seed germination begins with water soaking, which initiates a sequence of metabolic changes that culminates in the emergence of the primary root in viable, non-dormant seeds (Carvalho and Nakagawa, 2000). Water absorption by a seed follows a triphasic pattern, and the time of each phase of germination depends on factors related to the seed, such as the permeability of the integument, the chemical composition, and the seed size. The soaking conditions, which include temperature, substrate composition, and the presence of plant regulators, are also important (Carvalho and Nakagawa, 2000).

The seeds of $P$. foetida var. glaziovii do not follow this triphasic pattern and show radicle protrusion after $120 \mathrm{~h}$ of soaking in water. This difficulty during germination was previously observed by Soares et al. (2012), who reported that $P$. foetida $\mathrm{L}$. seeds might require months to germinate, most likely due to dormancy.

In vitro propagation is a promising approach for generating aseptic seedlings and for reducing or overcoming dormancy, in addition to other possibilities, such as obtaining virus-free seedlings (Prammanee et al., 2011) and producing secondary metabolites (Passos et al., 2004; Rosa and Dornelas, 2012). Complete removal of the seed integument is an essential step for the in vitro germination of Passiflora edulis f. flavicarpa (Dias et al., 2009; Rêgo et al., 2011), P. cincinnata (Dias et al., 2009; Dias et al., 2010), P. foetida (Rosa and Dornelas, 2012), and $P$. foetida var. glaziovii.Temperature also directly influences germination because it can affect water absorption and the biochemical reactions involved in metabolism. These factors all vary according to the particular species, which will have a specific temperature range within which its seeds will germinate (Zucareli et al., 2009). As found for P. foetida var. glaziovii, alternating temperatures of $20-30{ }^{\circ} \mathrm{C}$ were most favourable for the germination of Passiflora edulis $\mathrm{f}$. flavicarpa Deg. (Osipi and Nakagawa, 2005) and Passiflora alata Dryander (Zucareli et al., 2009). This behaviour suggests a probable adaptation to natural fluctuations in the environmental temperature (Borges and Rena, 1993). 
Table 2. Percentage of normal and defective seedlings and hypocotyl length $(\mathrm{cm})$ of $P$. foetida var. glaziovii under different light qualities.

\begin{tabular}{|c|c|c|c|c|}
\hline \multirow[b]{3}{*}{ Light quality } & \multicolumn{4}{|c|}{ Features } \\
\hline & 14 days & 30 days & & \\
\hline & $\begin{array}{l}\text { Normal } \\
\text { seedlings } \\
(\%)\end{array}$ & $\begin{array}{l}\text { Normal } \\
\text { seedlings } \\
(\%)\end{array}$ & $\begin{array}{l}\text { Defective seedlings } \\
(\%)\end{array}$ & $\begin{array}{l}\text { Hypocotyl } \\
\text { length } \\
(\mathrm{cm})\end{array}$ \\
\hline White & $33.5 \mathrm{a}^{*}$ & $35.1 \mathrm{a}$ & $44.6 \mathrm{a}$ & $4.3 \mathrm{c}$ \\
\hline Red & $31.0 \mathrm{a}$ & $41.0 \mathrm{a}$ & $43.5 \mathrm{a}$ & $6.3 \mathrm{~b}$ \\
\hline Far-red & $31.0 \mathrm{a}$ & $35.5 \mathrm{a}$ & $48.5 \mathrm{a}$ & $9.1 \mathrm{a}$ \\
\hline Darkness & $44.0 \mathrm{a}$ & $48.0 \mathrm{a}$ & $42.5 \mathrm{a}$ & $10.8 \mathrm{a}$ \\
\hline
\end{tabular}

*Averages followed by same letter indicate no significant differences according to the Tukey test, $\mathrm{p}>0.05$.

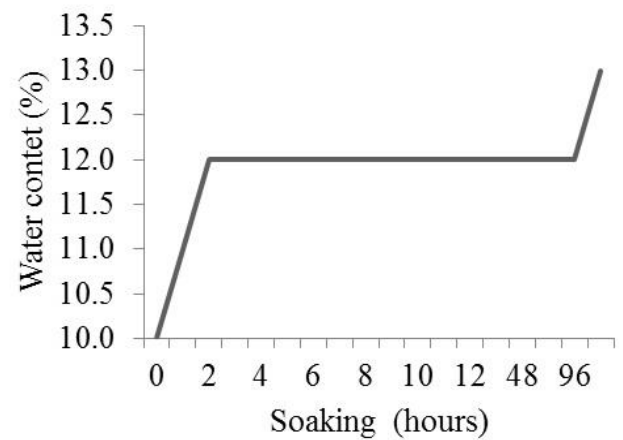

Fig 2. Soaking curve for P. foetida var. glaziovii seeds.

Temperature is usually associated with light, an important factor affecting germination, and the effect of light can be positive, negative or neutral (Balaguera et al., 2010). The non-photoblastic character of $P$. foetida var. glaziovii seeds facilitates their germination in environments with high, low or no light levels. Therefore, this species can occupy different micro-habitats in the forest or even on ground covered with a layer of stones or leaves (Vieira et al., 2010).

Although the germination test is most often used for evaluating seed vitality, the tetrazolium (TZ) test is gaining popularity due to certain advantages (Ista, 2004). The TZ test considerably reduces the time needed to assess germination potential, which is especially useful when the seeds must be sown immediately after harvesting (Brasil, 2009; Hosomi et al., 2012). Other advantages include insensitivity to fungi, low cost and the possibility of estimating vigor as well as the possibility of assessing viability in seeds that are dormant or that germinate slowly (Ista, 2004; Ribeiro et al., 2010; Grzybowski et al., 2012). In addition, according to the International Seed Testing Association (Ista, 2004), the TZ test has the potential to resolve problems detected in the germination test when the reasons for seedling abnormalities are unclear.

However, using the TZ test requires experience because the evaluation and interpretation of the results from $\mathrm{TZ}$ staining should be performed individually using a stereomicroscope, and decisions must be made at the time of reading (Custódio et al., 2012). Nevertheless, the use of digital images, which can be stored, expanded and subsequently evaluated in more detail, helps to reduce errors (Custódio et al., 2012). Hosomi et al. (2011) used TZ images to evaluate Cattleya sanguiloba and Cattleya granulosa seeds and were able to identify viable, unviable, or empty seeds.

Moreover, the lack of reference of TZ staining patterns for Passiflora makes it difficult to evaluate the results. In some studies in which the TZ test was performed to evaluate the viability of Passifloraceae seeds, such as in $P$. alata (Zucareli et al., 2003; Ferreira et al., 2005) and P. setacea (Pádua et al., 2011), no images were provided that could be used for comparison with other species, such as in the present study ( $P$. foetida var. glaziovii). When the hard seeds of $P$. alata were evaluated by the TZ test to determine the percentage of dormant and damaged seeds, viable seeds showed red or pink staining, whereas unviable seeds were milky-white or red (Zucareli et al., 2003). Pádua et al. (2011) evaluated the seeds of $P$. setacea and observed that viable seeds showed pinkish colouration in at least half of the cotyledons and throughout the embryonic axis. These examples highlight the importance of standardisation and comparison between staining results. The choice of appropriate methodologies for the use of $\mathrm{TZ}$ should be based on how easily viable and non-viable seeds as well as different physiological qualities can be differentiated. According to Azerêdo et al. (2011) and Clement et al. (2012), the results obtained in the TZ viability test and the germination test should be similar, allowing for no more than a $5 \%$ difference.

\section{Materials and Methods}

\section{Plant materials}

Samples of $P$. foetida var. glaziovii Killip from the Experimental Farm of the University Centre of Northern Espírito Santo (CEUNES)/Federal University of Espírito Santo (UFES) were collected, propagated by cuttings, and cultivated under controlled conditions in a greenhouse.

\section{Morphometry of fruits and seeds de $\mathbf{P}$. foetida var. glaziovii}

Taxonomic identification, morphological characterisation, and terminology were in accordance with Vidal and Vidal (2000). Seed size - The length, width, and thickness of 50 seeds were measured using fine-precision $(0.1 \mathrm{~mm})$ digital callipers. All measurements were performed according to Perez-Cortez et al. (2002); the length was determined from the top to the base, and the width and thickness were determined from the medial region. 
Table 3. Staining patterns of $P$. foetida var. glaziovii embryos subjected to the tetrazolium test and vitality classes related to the development of in vitro-cultivated seedlings.
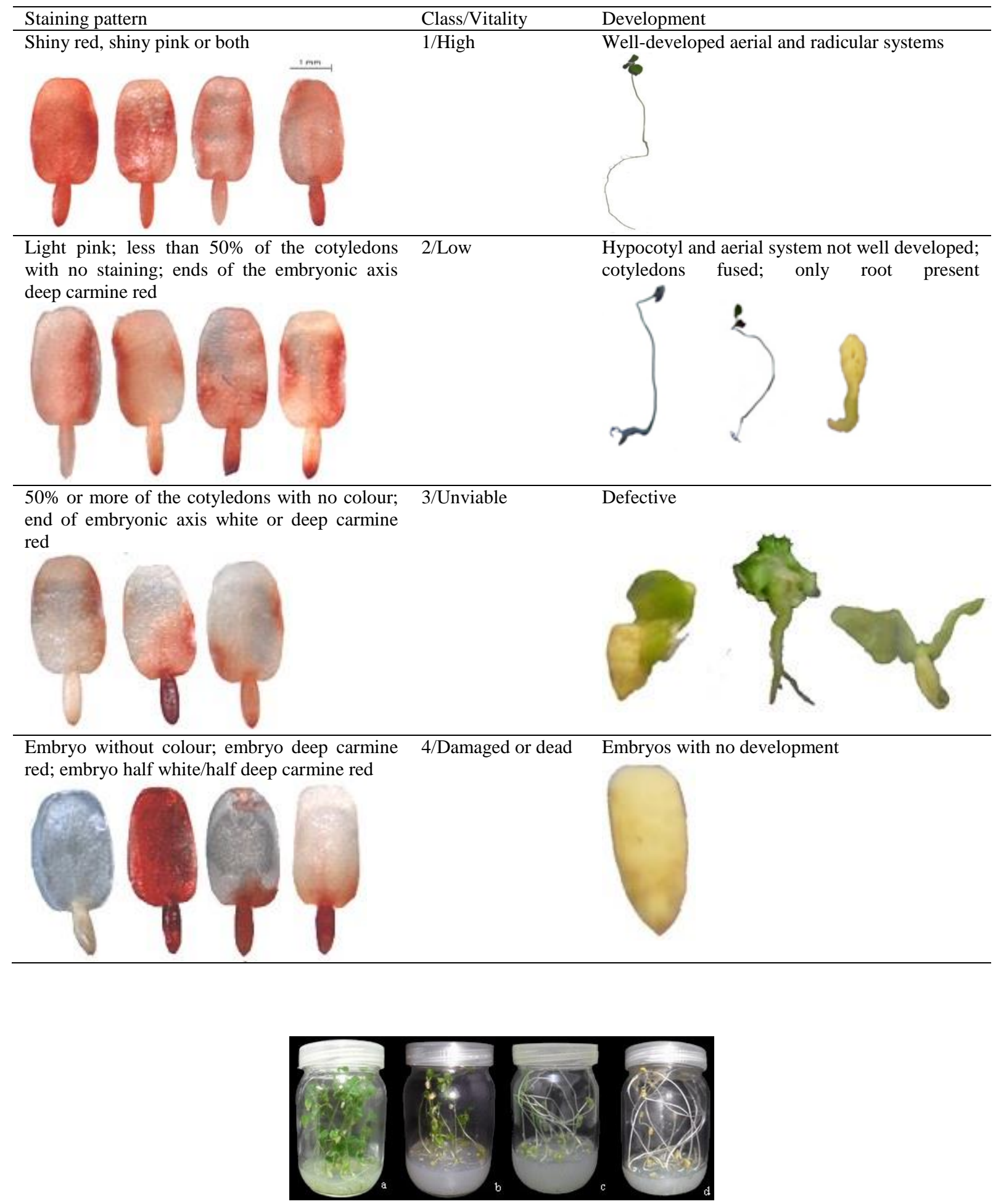

Fig 3. P. foetida var. glaziovii samples after $30 \mathrm{~d}$ of conditioning under white light (a), red light (b), far-red light (c), and darkness (d). 
Table 4. Comparison of the frequencies (number and percentage) of viable and unviable embryos between the tetrazolium and in vitro germination tests.

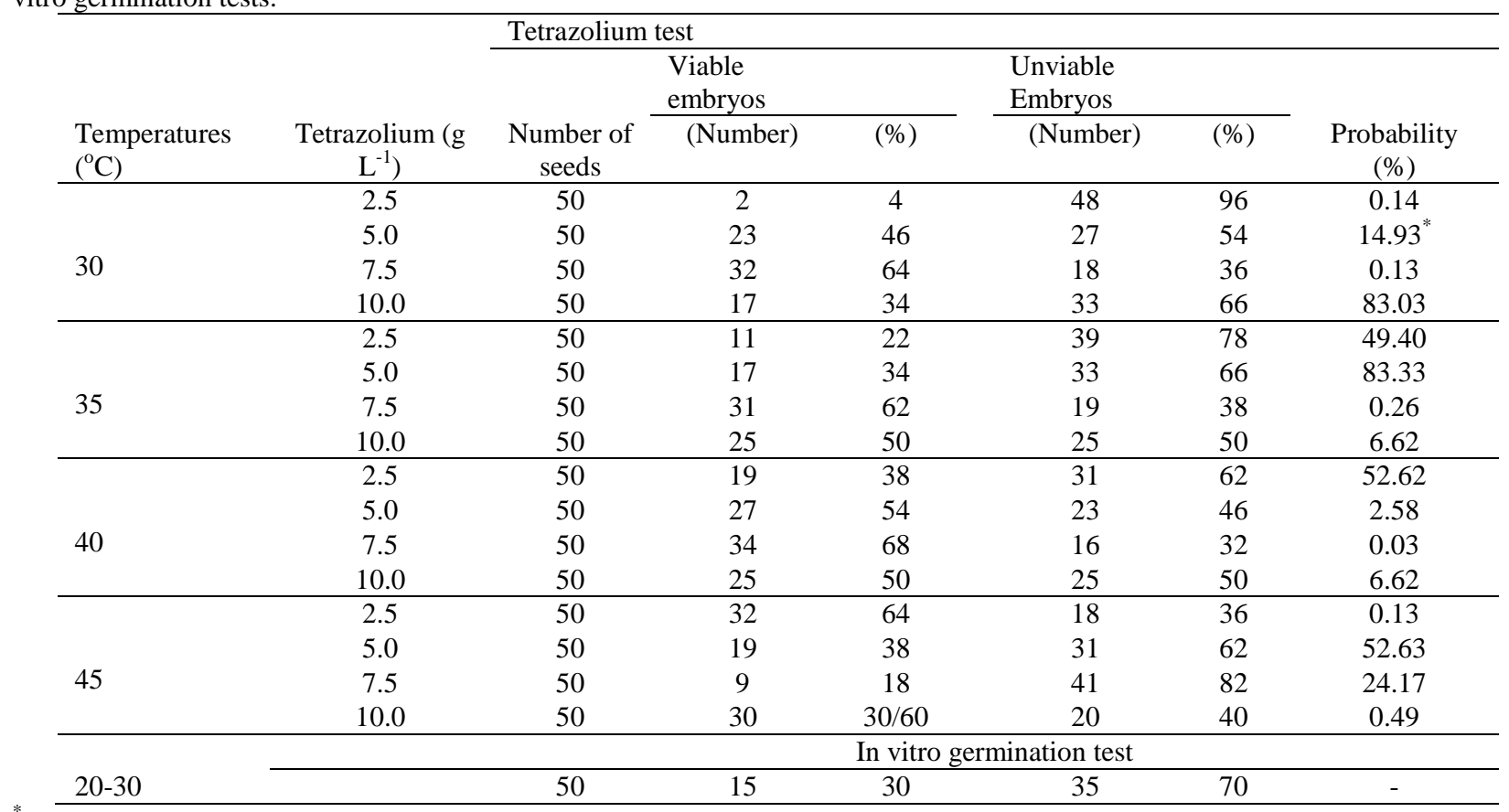

*Values of $\mathrm{p}>0.05$ do not differ statistically from in vitro germination test.

Table 5. Comparison of the frequencies from the tetrazolium and in vitro germination tests with respect to seedling growth.

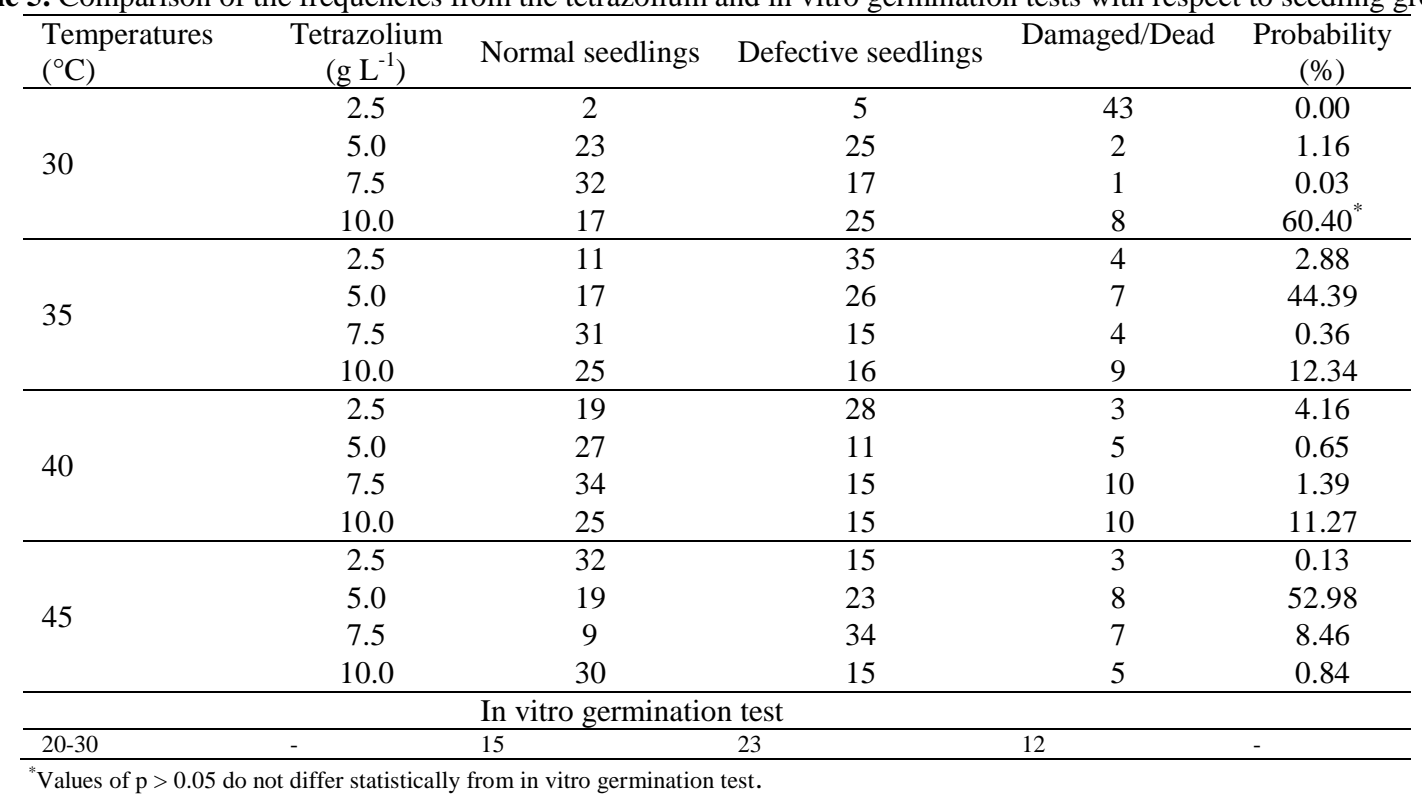

\section{Seed germination potential}

The arils of the seeds were completely removed using calcium oxide by rubbing on a plastic strainer and washing under running water. The seeds were placed on blotting paper for $72 \mathrm{~h}$ at ambient temperature $\left(25^{\circ} \mathrm{C}\right)$ for dehydration and analysis.

Water content - The water content was determined by the kiln method at $105 \pm 3{ }^{\circ} \mathrm{C}$ for $24 \mathrm{~h}$. Seed weight was measured for four replicates of 50 seeds, and the data are expressed as percentages (Brasil 2009).

Electrical conductivity - Four replicates of 50 seeds were weighed and immersed in plastic cups containing $75 \mathrm{~mL}$ of distilled water. The seeds were kept in a BOD at $25{ }^{\circ} \mathrm{C}$ for 24 h. After this time, the electrical conductivity of the soaking solution was analysed using an EC-1382 conductivity analyser, with the results are presented in $\mu \mathrm{S} \mathrm{cm} \mathrm{g}^{-1}$ (Barbosa et al., 2012).

Soaking curve - Soaking was performed at ambient temperature $\left(25{ }^{\circ} \mathrm{C}\right)$ with two replicates of 50 seeds. The seeds were uniformly aligned on two Germitest discs that had been wetted with distilled water to 2.5 times the weight of the dry paper. Analyses were performed every hour for the first $12 \mathrm{~h}$ and every $24 \mathrm{~h}$ thereafter. This method evaluates the water content over time.

Germination ex vitro - Four replicates of 50 intact seeds were germinated on three Germitest discs in Petri dishes containing two layers of Germitest discs wetted with distilled 
water to 2.5 times the weight of the dry paper. The seeds were kept in a BOD using constant $\left(25^{\circ} \mathrm{C}\right)$ and alternating (20 and $30^{\circ} \mathrm{C}$, night and day respectively) temperatures with a $12 \mathrm{~h}$ photoperiod. Evaluations were performed on days 14 and 30 following sowing, and the results are presented as the percentage of normal and defective seedlings (Brasil, 2009). Germination in vitro- Integuments were completely removed using a Mini-Morse, and the seeds were then placed in a laminar flow chamber where they were disinfected with $70 \%$ ethanol for one minute and a commercial sodium hypochlorite solution $(2.5 \%)$ for $15 \mathrm{~min}$. Next, the seeds were washed three times using distilled water and autoclaved. Glass bottles containing $50 \mathrm{~mL}$ of MS culture medium were used for sowing (Murashige and Skoog, 1962), with four replicates of 25 seeds under various temperatures $\left(25^{\circ} \mathrm{C}\right.$ and $20-30{ }^{\circ} \mathrm{C}$ ) and light quality (white, red, far-red and darkness). To determine the temperatures used, the conventional Passiflora edulis Sims methodology of Brasil (2009) was followed. White light was produced by four $20 \mathrm{~W}$ fluorescent lamps fastened internally to the door of the BOD. Red light was produced by overlaying two sheets of red cellophane, with far-red light produced using two sheets of blue cellophane in addition to the two sheets of red. Darkness was achieved by surrounding the glass bottles with Black bags (Menezes et al., 2004). All conditions were completely randomised using the simple factorial $2 \times 4$, with two temperatures and four light qualities. Averages were compared using the Tukey test (5\% probability) with the Genes software (Cruz, 2013).

Tetrazolium test - Integuments were completely removed from five replicates of 50 seeds, as described above, and the seeds were then pre-conditioned in distilled water for $12 \mathrm{~h}$ at ambient temperature $\left(25^{\circ} \mathrm{C}\right)$. The seeds were immersed for two hours in different concentrations of 2,3,5-triphenyl tetrazolium chloride $\left(2.5,5.0,7.5\right.$ and $\left.10 \mathrm{~g} \mathrm{~L}^{-1}\right)$ at $30,35,40$ and $45{ }^{\circ} \mathrm{C}$. After two hours, the samples were washed and immersed in distilled water to remove the embryos using a scalpel blade. Images were captured and analysed using a Leica SGD stereoscopic microscope and Leica EC3 camera. The colour intensity and embryo viability were classified as shiny red (strong and alive tissue), deep carmine red or light pink (damaged tissue), and whitish or yellowish (dead tissue).

\section{Statistical analysis}

In vitro germination was performed to associate staining patterns with the vitality classes. Five replicates with ten seeds were sterilised as described above. The seeds were kept in a BOD for $30 \mathrm{~d}$ at $20-30{ }^{\circ} \mathrm{C}$ with white light and a photoperiod of $12 \mathrm{~h}$ and then classified according to their developmental stages (Brasil, 2009). To compare the temperatures and the quality of light we used the Tukey test, $\mathrm{p}>0.05$. To analyse the association between $\mathrm{TZ}$ and in vitro germination, the number of embryos belonging to each class was calculated using the Chi-square test with $\mathrm{p}>0.05$ using Bioestat 5.0 software (Ayres et al., 2007).

\section{Conclusions}

This is the first record of Passiflora foetida var. glaziovii Killip in Espírito Santo State, Brazil. P. foetida var. glaziovii is a wild species characterised as an herbaceous vine with glandular trichomes on its leaves, bracts and stipules. The plant has small, approximately $4.87 \mathrm{~mm}$ long and $2.15 \mathrm{~mm}$ wide, non-photoblastic seeds, for which in vitro germination must be performed using a temperature regime of $20-30{ }^{\circ} \mathrm{C}$. The best results with the tetrazolium test were achieved using a combination of $10 \mathrm{~g} \mathrm{~L}^{-1}$ tetrazolium and a temperature of 30 ${ }^{\circ} \mathrm{C}$.

\section{Acknowledgments}

The authors thank Coordenação de Aperfeiçoamento de Pessoal de Nível Superior (CAPES, Brasília, Brazil) and Conselho Nacional de Desenvolvimento Científico e Tecnológico (CNPq, Brasília, Brazil) for financial support.

\section{References}

Araújo D, Alves M (2007) Variabilidade morfológica de Passiflora foetida L.: Quantas variedades existem no estado de Pernambuco? Rev Bras Bioc. 5(2): 852-854.

Azerêdo GA, Paula RC, Valeri SV (2011) Viabilidade de sementes de Piptadenia moniliformis Benth pelo teste de tetrazólio. Rev Bras Sement. 33(1): 61-68.

Ayres M, Ayres-Júnior M, Ayres DL, Santos AS (2007) Bioestat: aplicações estatísticas nas áreas das Ciências Biomédicas Versão 50 Belém Pará: Sociedade Civil Mamirauá MCT-CNPq: 324.

Balanguera HE, Álvarez JG, Cárdenas J (2010) Efecto de la estratificación fría y la cobertura plástica en semillas de gulupa (Passiflora edulis Sims) para la obtención de plântulas Rev UDCA Actual Divulg Cient. 13(2): 89-97.

Barbosa RM, Leão EF, Caprio CH, Vieira RD (2012) Teste de condutividade elétrica em sementes de maracujazeiroamarelo. Rev Bras Frutic. 34(2): 646-651.

Baskin CC, Baskin JM (1988) Germination ecophysiology of herbaceous plant species in a temperate region. Am J Bot. 75(2): 286-305.

Borges EEL, Rena AB (1993) Germinação de sementes IN: Aguiar IB, Pinã-Rodrigues FCM, Figliolia MB (Coord). Sementes florestais tropicais Brasília: ABRATES: 83-136.

Brasil. Ministério da Agricultura Pecuária e Abastecimento (2009) Regras para análise de sementes Ministério da Agricultura Pecuária e Abastecimento Secretaria de Defesa Agropecuária Brasília DF: Mapa/ACS: 395.

Carvalho NM, Nakagawa J (2000) Sementes: ciência tecnologia e produção. 4ed, Jaboticabal: Funep: 588.

Clemente ACS, Carvalho MLM, Guimarães RM (2012) Suitability of the tetrazolium test methodology for recently harvested and stored coffee seeds. Ciênc Agrotec. 36(4): 415-423.

Cruz CD (2013) Genes: a software package for analysis in experimental statistics and quantitative genetics. Acta Sci Agron. 35(3): 271-276.

Custódio CC, Damasceno RL, Machado Neto NB (2012) Imagens digitalizadas na interpretação do teste de tetrazólio em sementes de Brachiaria brizantha. Rev Bras Sement. 34(2): 334-341.

Dias LLC, Catarina CS, Ribeiro DM, Barros RS, Floh EIS, Otoni WC (2009) Ethylene and polyamine production patterns during in vitro shoot organogenesis of two passion fruit species as affected by polyamines and their inhibitor. Plant Cell Tiss Org Cult. 99: 199-208.

Dias LLC, Ribeiro DM, Catarina CS, Barros RS, Floh EIS, Otoni WC (2010) Ethylene and polyamine interactions in morphogenesis of Passiflora cincinnata: effects of ethylene biosynthesis and action modulators, as well as ethylene scavengers. Plant Growth Regul. 62: 9-19.

Faria FS, Stehmann JR (2010) Biologia reprodutiva de Passiflora capsularis L. e P. pohlii Mast (Decaloba Passifloraceae). Acta Bot Bras. 24(1): 262-269.

Ferreira G, Oliveira A, Rodrigues JD, Dias GB, Detoni AM, Tesser SM, Antunes AM (2005) Efeito de arilo na 
germinação de sementes de Passiflora alata Curtis em diferentes substratos e submetidas a tratamentos com giberelina. Rev Bras Frutic. 27(2): 277-280.

Gaspar-Oliveira CM, Martins CC, Nakagawa J (2009) Método de preparo das sementes de mamoneira (Ricinus communis L) para o teste de tetrazólio. Rev Bras Sement. 31(1): 160-167.

Grzybowski CRS, Ohlson OC, Silva RC, Panobianco M (2012) Viability of barley seeds by the tetrazolium test. Rev Bras Sement. 34(1): 47-54.

Hosomi ST, Custódio CC, Seaton PT, Marks TR, MachadoNeto NB (2012) Improved assessment of viability and germination of Cattleya (Orchidaceae) seeds following storage. In Vitro Cell Dev Biol Plant. 48: 127-136.

International Seed Testing Association. (2004). International rules for testing seeds Seed Science and Technology Supplement.

IPNI. The International Plant Names Index 2013 in http://wwwipniorg.

Marliére LDP, Ribeiro AQR, Brandão MGL, Klein CH, Acurcio FA (2008) Utilização de fitoterápicos por idosos: resultados de um inquérito domiciliar em Belo Horizonte (MG) Brasil. Rev Bras Farmacogn. 18: 754-760.

MENEZES NL, FRANZIN SM, ROVERSI T, NUNES EP (2004) Germinação de sementes de Salvia splendens Sellow em diferentes temperaturas e qualidades de luz. Rev Bras Sement. 26(1): 32-37.

Murashige T, Skoog F (1962) A revised medium for rapid growth and bioassays with tobacco tissue cultures. Physiol Plant. 15(30): 473-497.

Oliveira Júnior MX, São José AR, Rebouças TH, Morais OM, Dourado FWN (2010) Superação de dormência de maracujá-do-mato (Passiflora cincinnata Mast). Rev Bras Frutic. 32(2): 584-590.

Osipi EAF, Nakagawa J (2005) Efeito da temperatura na avaliação da qualidade fisiológica de sementes do maracujá-doce (Passiflora alata Dryander). Rev Bras Frutic. 27(1): 179-18.

Pádua JG, Schwingel LC, Mundim RC, Salomão AN, Roverijosé SCB (2011) Germinação de sementes de Passiflora setacea e dormência induzida pelo armazenamento. Rev Bras Sement. 33(1): 80-85.

Passos IRS, Matos GVC, Meletti LMM, Scott MDS, Bernacci LC, Vieira MAR (2004) Utilização do ácido giberélico para a quebra de dormência de sementes de Passiflora nitida Kunth germinadas in vitro. Rev Bras Frutic. 26(2): 380-38.

Pérez-Cortéz S, Tellet S, Escala M (2002) Estudio morfológico de la semilla de 51 especies del gênero Passiflora L. Acta Bot Venez. 25(1): 67-96.

Pires MV, Almeida AF, Figueiredo AL, Gomes FP, Souza MM (2012) Germination and seedling growth of ornamental species of Passiflora under artificial shade. Acta Sci Agron. 34(1): 67-75.

Prammanee S, Thumjamras S, Chiemsombat P, Pipattanawong N (2011) Efficient shoot regeneration from direct apical meristem tissue to produce virus-free purple passion fruit plants. Crop Prot. 30: 1425-1429.

Preisigke SC, Martini FV, Rossi AAB, Serafim ME, Barelli MAA, Luz PB, Araújo KL, Neves LG (2015) Genetic variability of Passiflora spp. against collar rot disease. Aust J Crop Sci. 9(1):69-74.
Rasool SN, Jaheerunnisa S, Jayaveera KN, Kumar CS (2011) In vitro callus induction and in vivo antioxidant activity of Passiflora foetida L leaves. Int J Appl Res Nat Prod. 4(1): $1-10$.

Rêgo MM, Rêgo ER, Bruckner CH, Finger FL, Otoni WC (2011) In vitro induction of autotetraploids from diploid yellow passion fruit mediated by colchicine and oryzalin. Plant Cell Tiss Org Cult. 107: 451-459.

Ribeiro LM, Garcia QS, Oliveira DMT, Neves SC (2010) Critérios para o teste de tetrazólio na estimativa do potencial germinativo em macaúba. Pesq Agropec Bras. 45(4): 361-368.

Rosa YBCJ, Dornelas MC (2012) In vitro plant regeneration and de novo differentiation of secretory trichomes in Passiflora foetida L (Passifloraceae). Plant Cell Tiss Org Cult. 108: 91-99.

Sathish R, Sahu A, Natarajan K (2011) Antiulcer and antioxidant activity of ethanolic extract of Passiflora foetida L. Indian J Pharmacol. 43(3): 336-339

Silva MIG, Gondim APS, Nunes LF, Souza FCF (2006) Utilização de fitoterápicos nas unidades básicas de atenção à saúde da família no município de Maracanaú (CE). Rev Bras Farmacogn. 16: 455-462.

Soares WS, Rêgo MM, Rêgo ER, Barroso PA, Nascimento KS, Ferreira KT (2012) Estabelecimento in vitro e micropropagação de maracujá silvestre (Passiflora foetida L.). Rev Bras Plantas Med. 14: 138-142.

Souza CR, Ohlson OC, Panobianco M (2010) Avaliação da viabilidade de sementes de aveia branca pelo teste de tetrazólio. Rev Bras Sement. 32(4): 174-180.

The Plant List. A Working list of all plant species. 2013 in http://www.theplantlist.org/tpl/search?q=Passiflora+foetida Tropicos Org. 2013in http://wwwtropicosorg.

Tropicos. Org. Passiflora foetida var. glaziovii Killip. http://www/tropicos.org. Acesso em 01: 01 fev. 2013.

Verdam MCS, Silva CB (2010) O estudo de plantas medicinais e a correta identificação botânica. Visão Acadêmica. 11(1): 7-13.

Vidal WN, Vidal MRR (2000) Botânica: organografia 4ed Viçosa: UFV: 114.

Vieira DCM, Socolowski F, Takaki M (2010) Germinação de sementes e emergência de plântulas de uma espécie exótica invasora Clausena excavate. Rev Bras Biol. 70(4): 10151020.

Zucareli C, Castro MM, Oliveira HR, Brancalião SR, Rodrigues JD, Ono EO, Boaro CSF (2003) Fitoreguladores e germinação de sementes de maracujá doce em condições de laboratório. Sci Agraria. 4(1-2): 9-14.

Zucareli V, Ferreira G, Amaro ACE, Araújo FP (2009) Fotoperíodo temperatura e reguladores vegetais na germinação de sementes de Passiflora cincinnata Mast. Rev Bras Sement. 31(3): 106-114. 